\title{
ПРОБЛЕМЫ ЭТНОГРАФИИ
}

УДК $398.5+930.85$

DOI: $10.17223 / 19988613 / 68 / 12$

Ю.Е. Березкин

СИБИРСКИЙ ФОЛЬКЛОР И ЕГО СОСЕДИ

Работа выполнена в рамках гранта РНФ № 18-18-00361.

Статья представляет расширенный вариант доклада, прочитанного на юбилейной ХVIII Международной Западносибирской археолого-этнографической конференции «Западная Сибирь в транскультурном пространстве Северной Евразии: итоги и перспективы 50 лет исследований ЗСАЭК», состоявшейся 16-18 декабря 2020 г. на базе Томского государственного университета.

С использованием факторного анализа выявлены комплексы мотивов в фольклоре и мифологии Сибири. Древнейший содержит американские параллели и относится к концу плейстоцена. Из более поздних один мотив связывает Сибирь с Восточной и Юго-Восточной Азией и отличен от традиций Кавказа и Европы. Второй объединяет Сибирь с Восточной Европой и отличен от южных традиций (от Атлантики до Юго-Восточной Азии). Два самых поздних набора мотивов Евразии соответствуют один христианским, а противоположный исламским и степным традициям.

Ключевые слова: фольклор и мифология; точные методы в гуманитарных науках; доистория Сибири.

Совокупность фольклорных мотивов в пределах региона напоминает совокупность галлогрупп в генофонде его населения. В обоих случаях современные данные позволяют проследить историю формирования выявленной картины. Разница в том, что гены наследуются, а мифы и сказки заимствуются не только от предков, но и от соседей.

Мы будем говорить о статистических тенденциях распределения материала. За каждой из них - десятки тысяч текстов. Не имея возможности рассмотреть отдельные мотивы, число которых приближается к трем тысячам, мы направляем читателя к электронному каталогу, в котором приведены резюме текстов (http://www.ruthenia.ru/folklore/berezkin). Актуальные карты распространения мотивов и их определения доступны по адресу: http://mapsofmyths.com. Сайт имеет логин (customer) и пароль (aether), но для специалистов они не тайна.

Определимся с терминами. «Мотив» есть эпизод или образ, выделенный в двух или более традициях. «Традиция» есть совокупность текстов, зафиксированных в пределах определенной этно-языковой общности или территории.

Мотивы бывают простыми или сложными, единственный критерий правильности их выделения - характер ареала. Историческую информацию несут лишь мотивы, которые встречаются на одних территориях, но отсутствуют на других. Распределение мотивов по традициям есть способ привязать материал к географическим координатам. Это легче сделать, постулируя соответствие между традициями и языками. Но если язык занимает большую территорию, то традицию необходимо дробить, поскольку наборы мотивов в удаленных друг от друга районах не бывают вполне одинаковыми.

Фольклор и мифология, точнее, форма и содержание повествований и представлений, - автономная сфера культуры, мало зависящая от сферы жизнеобеспечения. Это доказывается отсутствием заметной корреляции между ареалами распространения фольклорно-мифологических мотивов и природными, хозяйственными или социальными факторами. Зато корреляция прослеживается с направлениями миграций и культурных взаимодействий, известных по данным других исторических дисциплин. Поскольку передача устной традиции не требует значимых затрат, время жизни мотивов не ограничено. Соответственно, в конфигурации ареалов распространения мотивов мифологии и фольклора может сохраняться информация о разных периодах.

Мотивы распределены по двум категориям. Категория А в основном представлена мотивами, выделенными из мифологической прозы или полученными путем опроса информантов. Мотивам категории Б соответствуют (с оговорками и частично) повествовательные эпизоды из фольклорных указателей по системе ATU [1]. Первые можно именовать мифологическими в узком смысле, а вторые - сказочными. Это деление существенно для Старого Света, но не для Америки, где отличного от мифологической прозы сказочного фольклора не было.

Сказанное не значит, что все эпизоды евразийской сказки появились недавно. Некоторые могли возникнуть и распространиться задолго до того, как оказались использованы в сказочных сюжетах. Об этом свидетельствует наличие ряда подобных мотивов как в Азии, так и в Америке. 
Данные проанализированы с помощью факторного анализа. Он подходит для материала, в котором новые общности формируются не только филогенетически, но и путем обмена элементами между неродственными группами (подробнее см.: [2]). Использована стандартная программа IBM SPSS Statistics Version 19. Параллели между традициями образуют сеть разнонаправленных связей. Факторный анализ позволяет выделить основные тенденции - главные компоненты (ГК). Значимы несколько первых, остальное - информационный шум. Если традиции сильно различаются числом мотивов, программа воспринимает плохо изученные как объективно отличные от богатых, противопоставляя одни другим. Подобная оппозиция для нас не важна, и если ее отражает 1ГК, то наиболее значимой оказывается $2 \Gamma$ К.

Каждой ГК соответствуют две совокупности традиций, по составу мотивов наименее похожих. Программа наделяет их индексами со знаком «+» либо «-». Чем ярче отражена тенденция, тем абсолютная величина индекса выше. О тенденциях распределения мотивов надо судить по богатым традициям с высокими индексами. «Плюсом» оценивается та группа традиций, в которой свойственный ей набор мотивов представлен лучше, чем в противоположной группе. Каждая группа с индексами одного знака соответствует общности, обмен информацией внутри которой шел интенсивней, чем с другими общностями. О каких именно общностях и эпохах идет речь, по материалам самих фольклора и мифологии судить невозможно. Для этого полученные результаты надо сравнивать с данными письменной истории, археологии, генетики и лингвистики.

Внутри категорий мотивов можно выделить более узкие группы. Среди составляющих категорию А (космология и этиология) группа 2 включает мотивы, отражающие представления об объектах ночного неба, а группа 5 - представления об антропогенезе, человеческой анатомии, отношениях полов и т.п. Мотивы с сексуальной тематикой в бытовых сказках и анекдотах сюда не относятся.

Хотя обе темы (звездное небо и человек) универсальны, мотивы двух названных групп дают разное ареальное распределение. Мотивы группы 5 типичны для индо-тихоокеанского мира (рис. 1), а мотивы группы 2 - для Северной Евразии (рис. 2). Большинство соответствующих североамериканских мотивов находит параллели в Сибири, где они, вероятно, и сформировались [3]. Самая богатая звездная мифология зафиксирована в Европе, но поскольку большинство европейских космонимов отражает реалии железного века и Средневековья [4. С. 180-210], область формирования звездной мифологии вряд ли находилась далеко на западе - скорее, она охватывала всю Северную Евразию. В Южной Азии мотивы, отражающие представления об объектах ночного неба, в основном представлены у индо-арийских народов, а наиболее обильно в древнеиндийской традиции, так что связь с миграцией индоариев крайне вероятна. И напротив: мотивы, отражающие представления об анатомии и об отношениях полов, популярны у мунда, тибето-бирманцев и небольших дравидских народов Средней Индии.

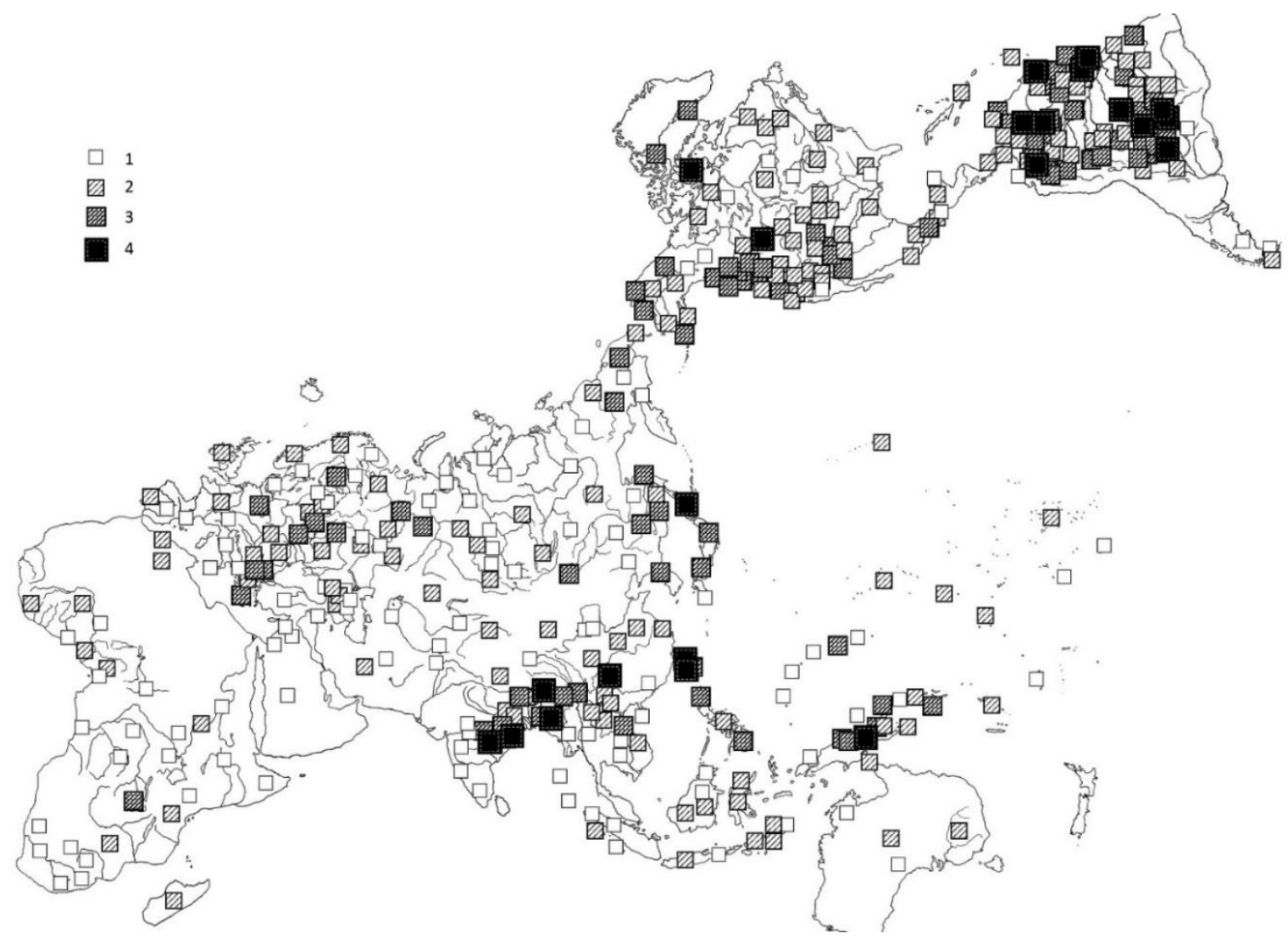

Рис. 1. Число мотивов, отражающих представления об антропо- и социогенезе, отношениях полов, человеческой анатомии: $1-3-6 ; 2-7-11 ; 3-12-17 ; 4-18-30$. Традиции с числом мотивов $<3$ не показаны 


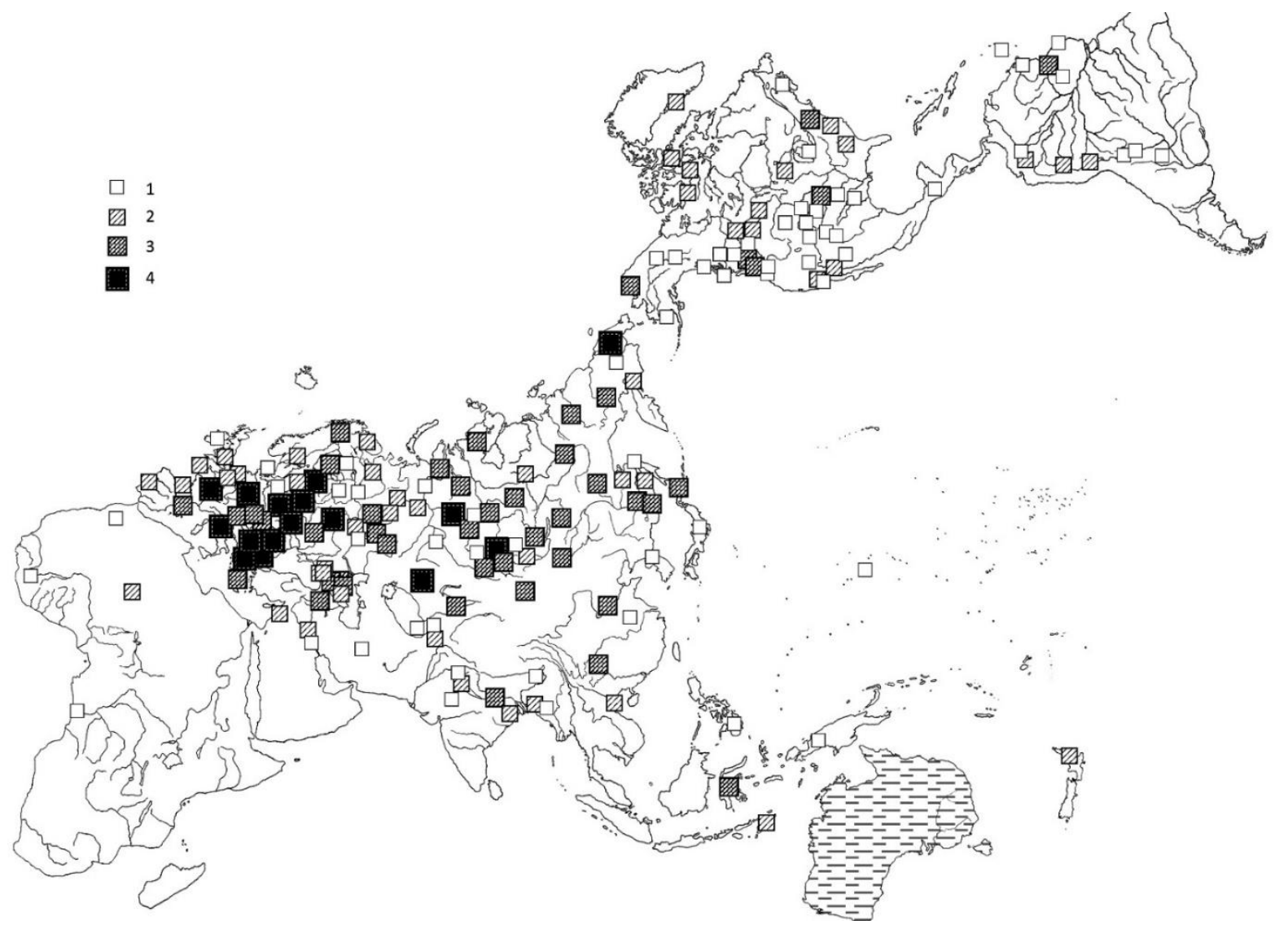

Рис. 2. Число мотивов, отражающих представления об объектах ночного неба: 1 - 10-12; 2 - 13-16; 3 - 17-24; 4 - 25-47. Традиции с числом мотивов $<10$ не показаны. В Австралии большинство астральных мотивов не имеет аналогий за пределами континента и не классифицировано

В Африке южнее Сахары мотивы обеих групп (2 и 5) встречаются редко, но много тех, которые связаны c темой появления смерти. Можно полагать, что «смертные» мотивы были знакомы уже ранним сапиенсам эпохи выхода из Африки и затем были принесены на другие континенты [5]. Представления о звездном небе и антропогонические мифы распространились позже - одни в континентальной Евразии, а другие в индо-тихоокеанском мире. Поскольку эти регионы долго оставались весьма изолированными друг от друга и заселялись разными группами сапиенсов, развитие мифологии в них шло разными путями.

Существуют параллели между наборами мотивов в Южной и Центральной Америке, с одной стороны, и Меланезии - с другой. В основном речь идет именно о мотивах группы 5 (антропогенез и отношения полов). Чтобы оказаться в Америке, они должны были быть известны по всей циркумтихоокеанской дуге. След данного комплекса на Дальнем Востоке заметен вплоть до Амура и Сахалина, а затем он вновь появляется на северо-востоке Азии и на Аляске (см. рис. 1). Самый ранний фольклорно-мифологический слой, который можно выделить в континентальной Евразии, включает параллели между Сибирью и Северной Америкой. Актуальная оценка начала заселения Америки 16,600-15,100 кал. л.н., сразу после завершения ледникового максимума [6, 7]. Параллелей с Южной Америкой в континентальной Евразии мало. Сибирские мотивы характерны либо для северо-запада и се- вера североамериканского континента, либо для его более южных областей, располагавшихся за границей Лаврентийского ледника. Логично предположить, что первые относятся к голоцену, когда американская Арктика стала пригодной для обитания, а вторые - ко времени, когда ледник еще не растаял, и, соответственно, к финальному плейстоцену.

Статистика это заключение подтверждает. При обработке мотивов, известных как в Евразии, так и в Америке, 1ГК показывает наличие в Новом Свете двух комплексов: индо-тихоокеанского и континентальноевразийского (рис. 3). Первый прослеживается вплоть до Арктики, но второй не пересекает мексиканской границы. Вторая ГК в пределах той же совокупности мотивов показывает наличие североамериканских параллелей в Сибири вплоть до Урала (рис. 4). В Новом Свете речь идет о традициях, зафиксированных не только к югу от области распространения Лаврентийского ледника, но также в Арктике и Субарктике. Данный набор мотивов должен быть более поздним, чем тот, который фиксирует 1ГК.

Обратимся к сравнению традиций в пределах только Старого Света. На рис. 5 отражены результаты обработки мотивов категории А (собственно мифологических). Мы видим два комплекса, восточный и западный. В пределах восточного Сибирь оказывается важнейшим центром разнообразия. Западный комплекс - европейско-кавказский, но в ослабленном виде он тянется на восток до Синьцзяна. 


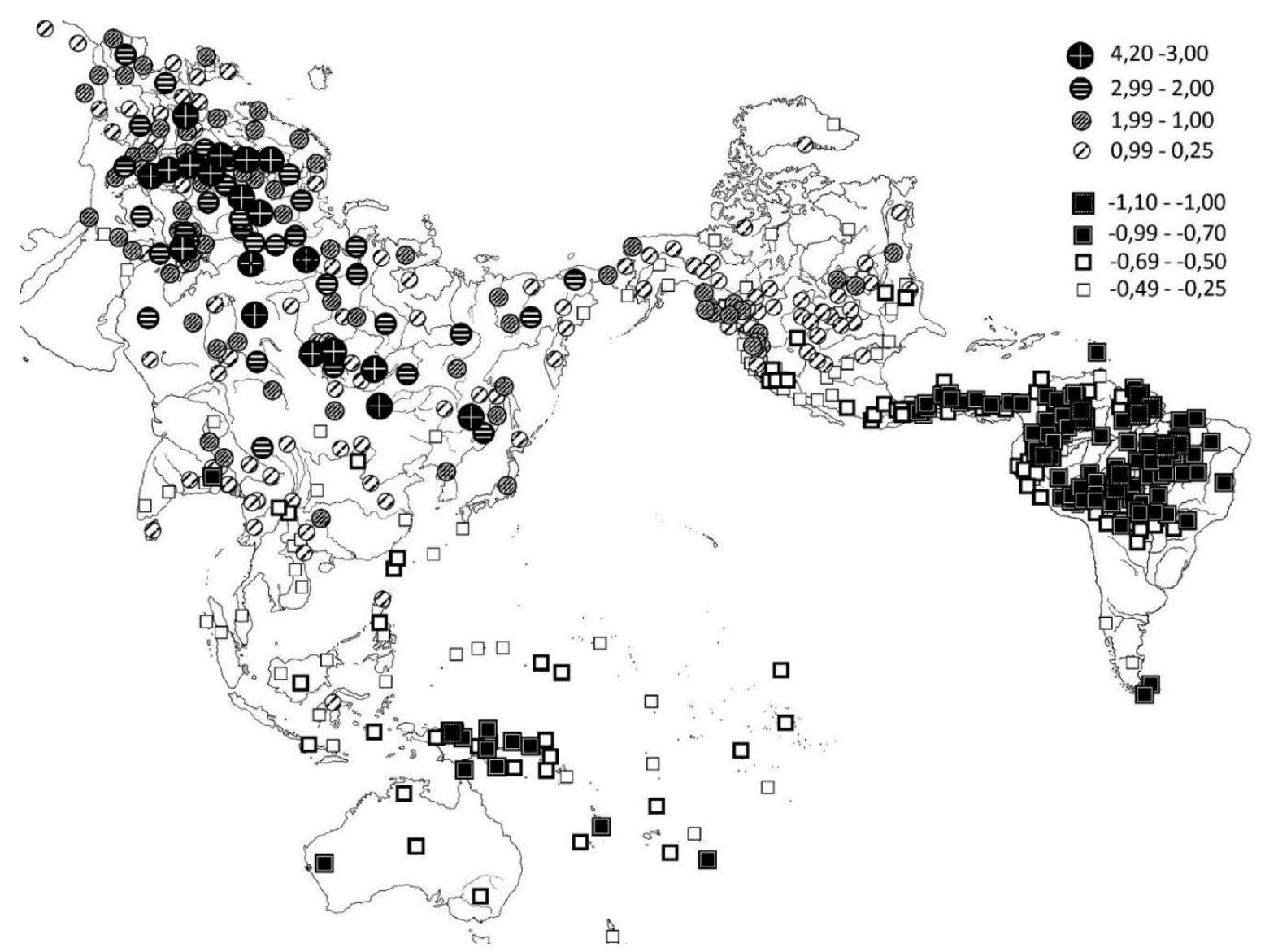

Рис. 3. Результаты обработки распределения 878 мотивов всех категорий, известных как в Новом, так и в Старом Свете (без Африки южнее Сахары), 1ГК. Дисперсия 3,9\%. Традиции с числом мотивов $<21$ и с индексами от 0,24 до $-0,24$ не показаны

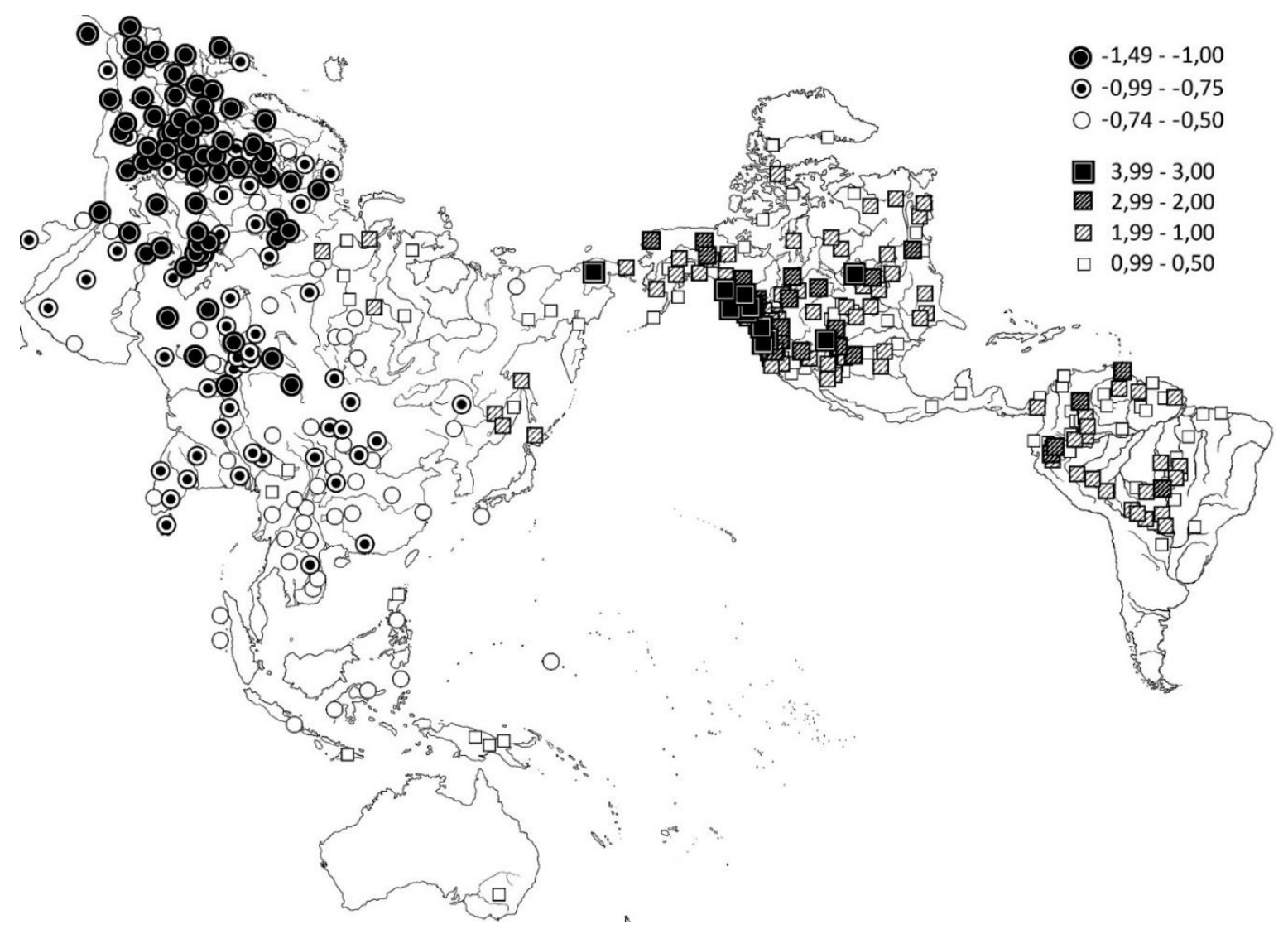

Рис. 4. Результаты обработки тех же данных, что и на рис. 3, 2ГК. Дисперсия 3,4\%.

Традиции с числом мотивов $<21$ и с индексами от 0,49 до $-0,49$ не показаны 


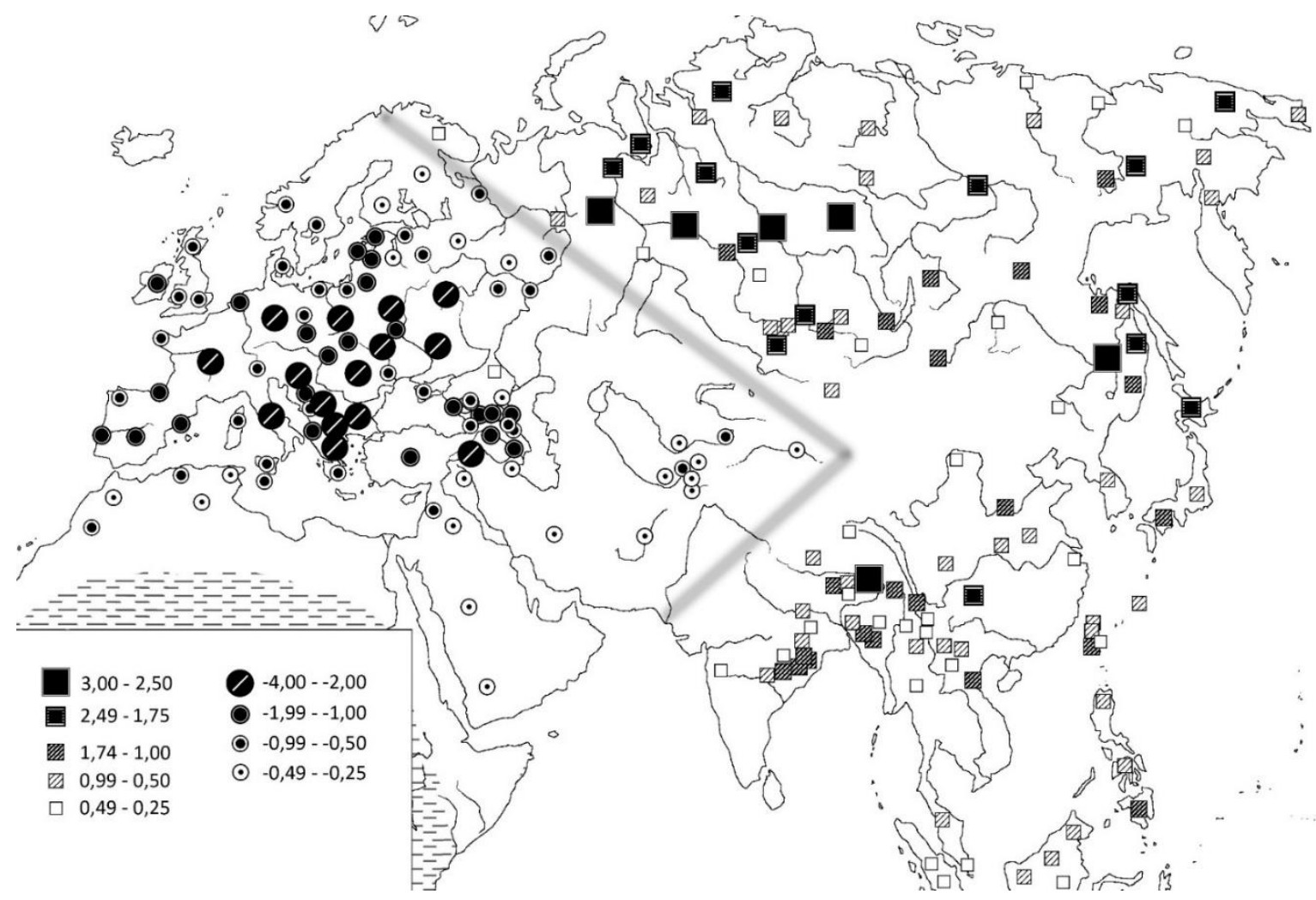

Рис. 5. Результаты обработки данных о распределении 626 мотивов в Евразии и Северной Африке, связанных с космологией и этиологией, 2ГК. Дисперсия 3,8\% (3,65). Традиции с числом мотивов $<10$ и с индексами от 0,24 до -0,24 не показаны. 3десь и далее намечена примерная граница двух комплексов мотивов

Восточный комплекс окружает его с севера, востока и юга. На юге Азии полюсом относительной недоступности от внешних влияний являются Восточные Гималаи. Именно здесь набор зафиксированных мотивов ближе всего сибирскому.

В порядке гипотезы подобную картину допустимо связать с историческими процессами III-II тыс. до н.э. В это время европейцы проникли по степи далеко на восток (обратное движение с востока на запад преобладает лишь с гуннско-сарматского времени). Что касается принадлежности к одному комплексу традиций как Сибири, так и Юго-Восточной Азии, то здесь надо вспомнить микролитические индустрии Монголии и северного Китая, которые на протяжении всего верхнего палеолита расширяли свою территорию за счет галечных индустрий юга Китая [8. Fig. 1; 2, 9, 10]. Позже из Китая на юг и юго-запад распространились производящая экономика и бронза [11].

Теперь рассмотрим распределение эпизодов волшебной сказки. Третья ГК демонстрирует тенденцию, не похожую на данные обработки мотивов мифологии (рис. 6). Вся Сибирь вместе с Восточной Европой и Северным Кавказом противопоставлена территориям от Ирландии и Марокко до Средней Азии и Индокитая. Северо-восточный комплекс идеально вписывается в границы Российской империи, однако вряд ли русские существенно повлияли на фольклор чукчей, нанайцев или халха-монголов. Скорее, речь идет о фоне, субстрате, на основе которого (в период от середины I до середины II тыс. н.э.?) складывался набор сюжетов евразийской волшебной сказки. У него было два главных источника: переднеазиатский (с отдельными характерными эпизодами, известными еще в Древнем Египте и Шумеpe) и сибирский - в основном южносибирский.

Сопоставим рис. 6 и 7, где показаны результаты обработки эпизодов текстов другого жанра - сказки о животных. Картина похожа. Южный комплекс определенно включает в себя мотивы, распространявшиеся на основе письменной традиции («Панчатантра», «Калила и Димна», басни Эзопа и пр.). В этом контексте и в связи с распространением мировых религий соответствующие мотивы проникли вплоть до Южной Сибири и Казахстана. Древнерусская письменная традиция тоже связана с этим комплексом (круглый значок среди квадратных на рис. 7), а восточнославянские фольклорные традиции - с северным. Последний хорошо представлен как в Восточной Европе, так и на северовостоке Азии. Он не вполне сопоставим с совокупными данными касательно представлений об объектах ночного неба (см. рис. 2), но совпадения с ареалами фиксации отдельных космонимов [12] несомненны.

Деление Евразии на север и юг - вторая по значимости тенденция, которую показывает обработка эпизодов волшебной сказки. Главную же отражает $2 \Gamma К$, противопоставляя Европу Кавказу и Центральной Азии (рис. 8). На Средней Волге тюркоязычные традиции противоположны финно-угорским. В Средиземноморье албанцы и арабы Туниса и Алжира связаны с восточным комплексом, сицилийцы и мальтийцы - с западным. Такая картина отражает как экспансию тюрков и монголов, так и обособление исламской и христианской сфер взаимодействия. Тюрко- и монголоязычные традиции Южной Сибири характерны для восточного комплекса, а традиции остальной Сибири нейтральны. 


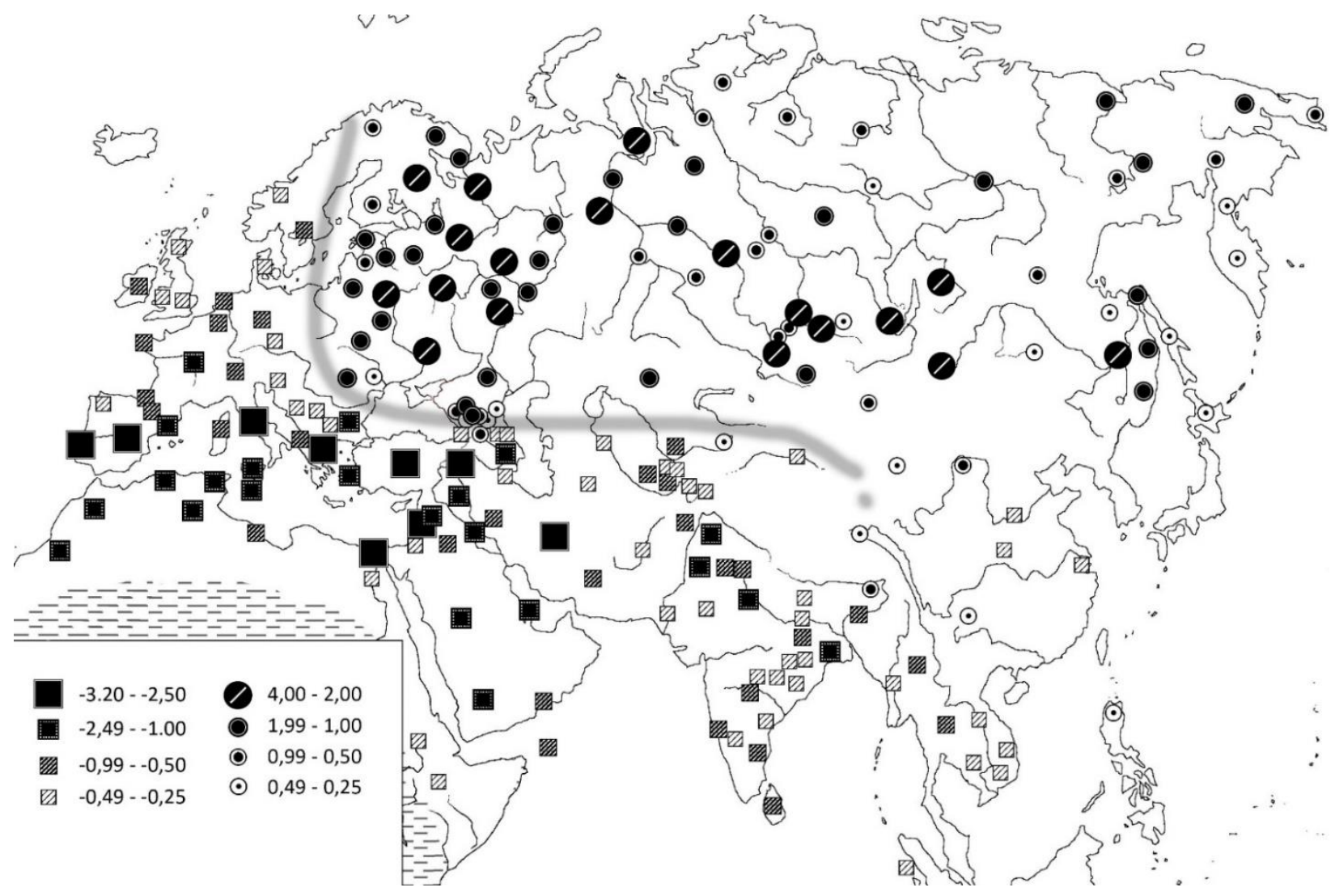

Рис. 6. Результаты обработки данных о распределении в Евразии и Северной Африке 720 эпизодов и 35 словесных клише (устойчивых сравнений), характерных для волшебной сказки, ЗГК. Дисперсия $3,1 \%$. Традиции с числом мотивов $<10$ и с индексами от 0,24 до $-0,24$ не показаны

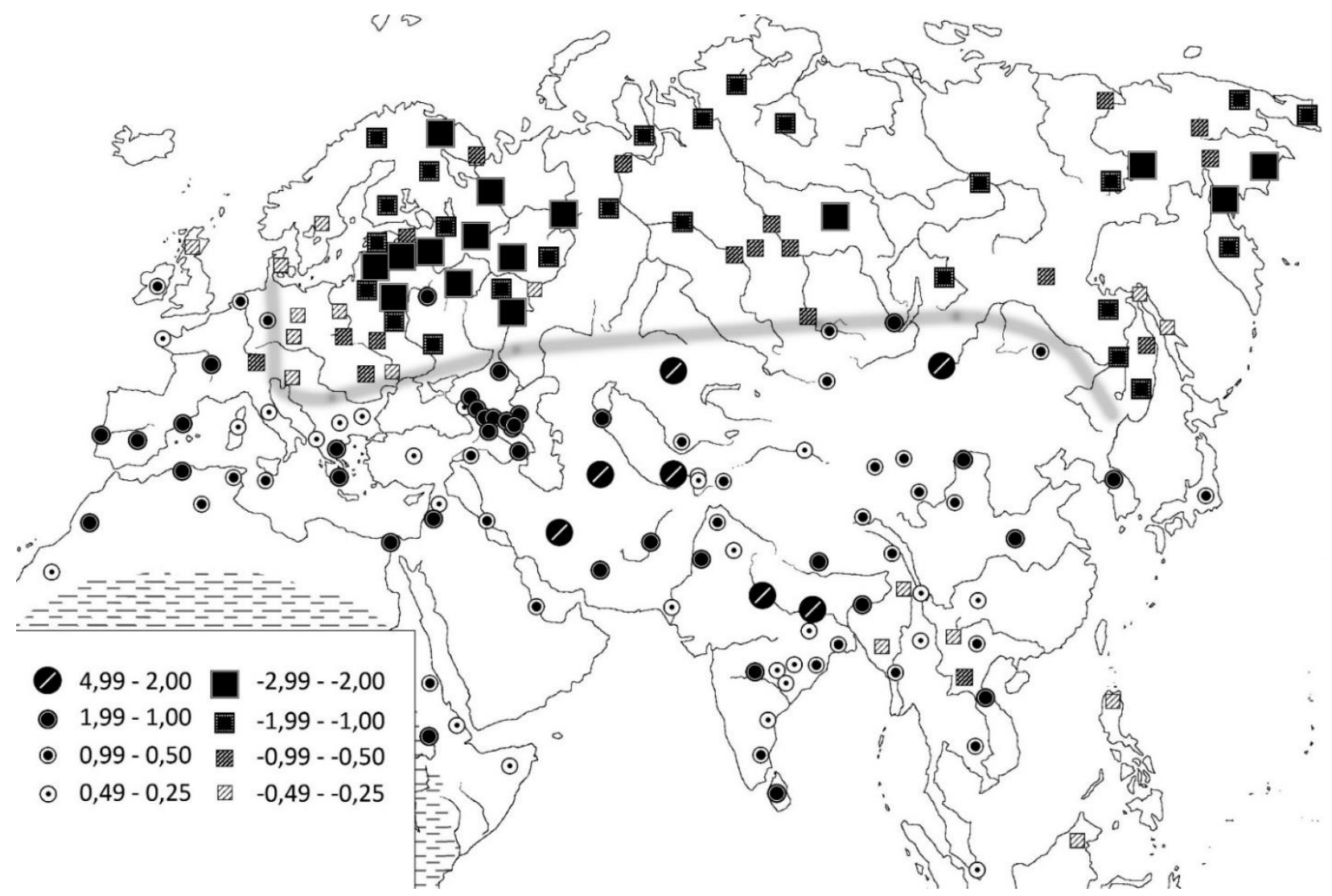

Рис. 7. Результаты обработки данных о распределении в Евразии и Северной Африке 223 эпизодов сказки о животных, 2 ГК. Дисперсия 4,0\%. Традиции с числом мотивов $<5$ и с индексами от 0,24 до $-0,24$ не показаны 


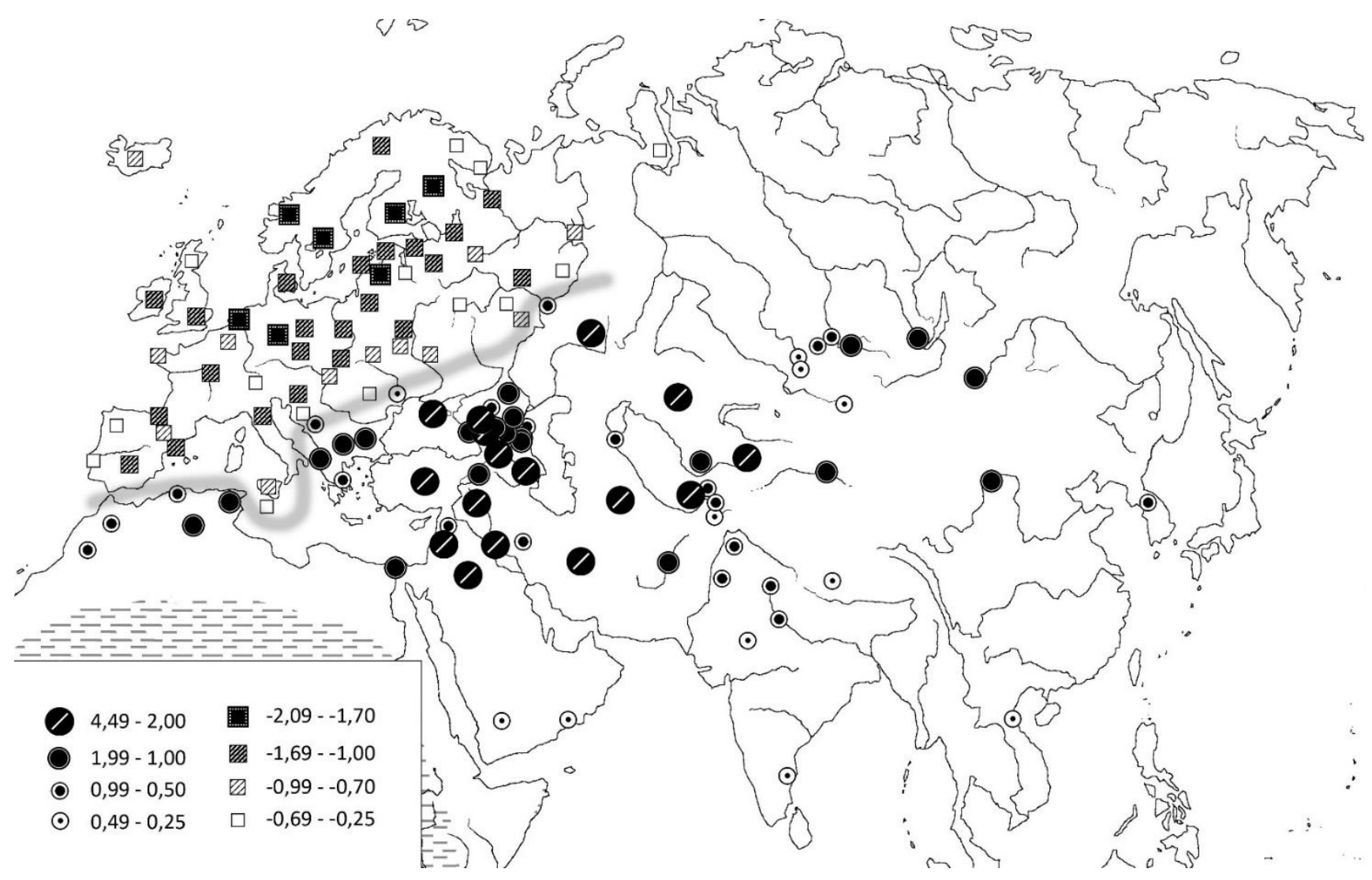

Рис. 8. Результаты обработки данных о распределении в Евразии и Северной Африке 719 эпизодов и 35 словесных клише, характерных для волшебной сказки, $2 Г К$. Дисперсия $4,2 \%$. Традиции с числом мотивов $<50$ и с индексами от 0,49 до $-0,24$ не показаны

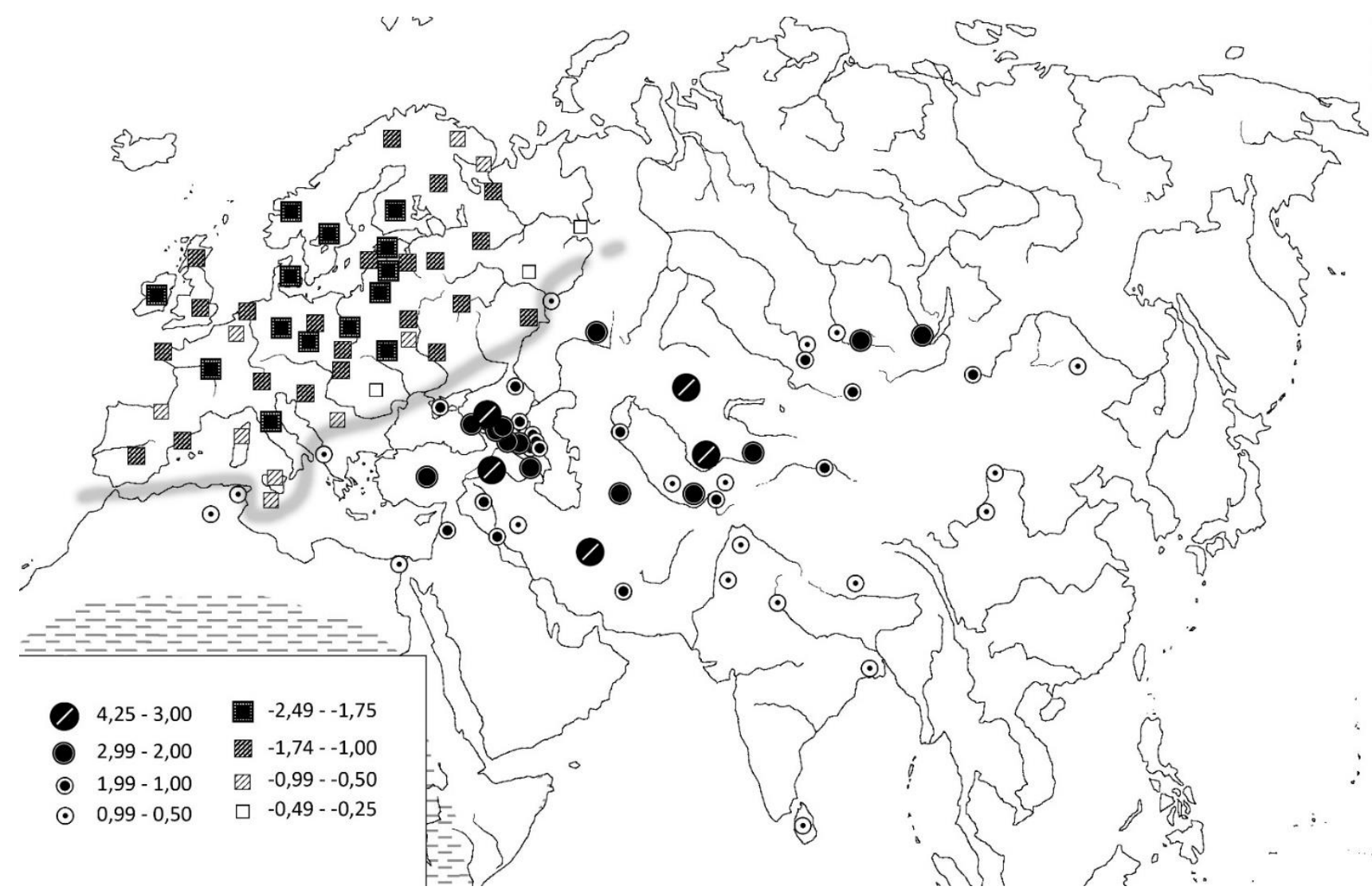

Рис. 9. Результаты обработки данных о распределении в Евразии и Северной Африке 176 эпизодов, характерных для бытовой сказки и анекдотов с участием людей, $2 Г К$. Дисперсия $5,8 \%$. Традиции с числом мотивов $<10$ и с индексами от 0,24 до $-0,24$ не показаны 
То, что подобное ареальное распределение отражает самый поздний срез традиционного фольклора, подтверждается аналогичным распределением трикстерских эпизодов (бытовая сказка и анекдот), в которых действуют только люди (рис. 9). Эта группа мотивов отражает реалии Средневековья и начала Нового Времени. Совпадение соответствующих тенденций распределения для бытовой и волшебной сказки показывает, что наборы мотивов в последней окончательно оформились не раньше середины II тыс. н.э. В то же время в волшебной сказке (рис. 6) и в сказке о животных (рис. 7) есть и ранний компонент, отражающий деление Евразии на север и юг, т.е. на пояс цивилизаций и зону к северу от них. Контакты внутри каждого из этих регионов были значимее межрегиональных.

\section{Заключение}

После того как сапиенсы вышли из Африки, они заселили индо-тихоокеанскую окраину Азии, где нашли примерно те же условия, что и на африканской прародине. Это произошло не позже 50-45 тыс. л.н. Более ранние датировки не общепризнаны. Тогда же сапиенсы пришли в континентальную Евразию, где природные условия были иными. Не позже 16 тыс. л.н. обитатели примыкающих к Тихому океану областей Азии проникли в Америку и принесли туда мифоло- гию, которая у них к тому времени возникла. Эта мифология лучше всего сохранилась в наиболее изолированных от Северной Азии регионах: Южной Америке и Меланезии. Сравнивая данные по этим регионам, можно очертить набор мотивов, которые обитатели Восточной Азии использовали в своих повествованиях 20-15 тыс. л.н. Для континентальной Евразии реконструкция возможна лишь с того времени, когда в Северную (но не в Южную) Америку стали проникать люди из удаленных от океана районов Сибири и Центральной Азии. Речь идет о конце плейстоцена, но датировка с точностью до тысячелетия невозможна. Объем статьи не позволяет рассмотреть вопрос о соотношении данных археологии, генетики и сравнительной мифологии касательно проникновения в Новый Свет домонголоидных популяций.

В плейстоцене Евразия делилась на континентально-евразийскую и индо-тихоокеанскую зоны, но для более поздних периодов прослеживаются другие деления: восток / запад и север / юг. Еще позже (последние полтора тысячелетия) два главных комплекса фольклорных мотивов отражают различия между христианской Европой и Азией (без Дальнего Востока). В последней соединились переднеазиатско-исламский и степной тюрко-монгольский компоненты.

Благодарю А.Г. Козиниева за помощь с литературой и замечания.

\section{ЛИТЕРАТУРА}

1. Uther H.-J. The Types of International Folktales. Helsinki : Suomalainen Tiedeakatemia, 2004. Pts. 1-3.

2. Berezkin Yu.E. Peopling of the New World in light of the data on distribution of folklore motifs // Maths Meets Myths: Quantitative Approaches to Ancient Narratives / Edited by Ralph Kenna, Máirín Mac Carron, and Pádraig Mac Carron. Cham, Switzerland : Springer Verlag, 2016. Pp. 71-89.

3. Березкин Ю.Е. Самодийская космология в сибирско-североамериканском контексте // Урало-алтайские исследования. 2018. № 2 (29). С. 18-29.

4. Березкин Ю.Е. Рождение звездного неба: представления о ночных светилах в исторической динамике. СПб. : МАЭ РАН, 2017. 316 с.

5. Berezkin Yu.E. Why are People Mortal? World Mythology and the "Out-of-Africa" Scenario // Ancient Human Migrations. A Multidisciplinary Approach / ed. by P.N. Peregrine, I. Peiros, M. Feldman. Salt Lake City : The University of Utah Press, 2009. P. $242-264$.

6. Prates L., Politis G.G., Perez S.I. Rapid radiation of humans in South America after the last glacial maximum: a radiocarbon-based study // PLoS One. 2020. July 22. URL: https://doi.org/10.1371/journal.pone.0236023

7. Williams T.J., Collins M.B., Rodrigues K., Rink W.J., Velchoff N., Keen-Zebert A., Gilmer A., Frederick C.D., Ayala S.J., Prewitt E.R. Evidence of an early projectile point technology in North America at the Gault Site, Texas, USA // Science Advances. 2018. Vol. 4. P. 1-7. DOI: 10.1126/sciadv.eaar5954

8. Bar-Yosef O., Belfer-Cohen A. Following Pleistocene road signs of human dispersals across Eurasia // Quaternary International. 2013. Vol. 285. P. 30-43.

9. Bar-Yosef O., Wang Y. Paleolithic archaeology in China // Annual Review of Anthropology. 2012. Vol. 41. P. $319-335$.

10. Qu T., Bar-Josef O., Wang Y., Wu X. The Chinese Upper Paleolithic: geography, chronology, and techno-typology // Journal of Archaeological Research. 2013. Vol. 21. P. 1-73.

11. Higham C., Higham T., Kijngam A. Cutting a Gordian Knot: the Bronze Age of Southeast Asia: origins, timing and impact // Antiquity. 2011. Vol. 85, № 328. P. 583-598.

12. Березкин Ю.Е. Плеяды-отверстия, Млечный Путь как Дорога Птиц, девочка на луне: североевразийские этнокультурные связи в зеркале космонимии // Археология, этнография и антропология Евразии. 2009. Т. 44, № 4. С. 100-113.

Yuri E. Berezkin, Peter the Great Museum of Anthropology \& Ethnography (Saint Petersburg, Russian Federation). E-mail: berezkin1@gmail.com

\section{THE SIBERIAN FOLKLORE AND ITS NEIGHBOURS}

Keywords: folklore and mythology; exact methods in the humanities; Siberian prehistory.

The research is based on Analytical Electronic Catalogue that contains information on the spread of ca. 3000 motifs in ca. 1000 traditions of the world. "The motif" is an episode or an image recorded in two or more traditions. "The tradition" is a set of texts recorded from the people who speak a particular language or live across a particular territory. Patterns of motifs' spread show no significant correlation with the territorial spread of other factors and processes besides large-scale migrations and cultural interactions. If the time of such processes is established thanks to the data of other historical disciplines, we are able to segregate particular regional and epochal complexes inside the amorphous mass of the motifs. The data are processed by factor analysis. This method can be applied to the material in which new units emerge not only phylogenically but also thanks to the exchange of the elements between genetically unrelated groups. It makes possible to select a few meaningful tendencies, the so called principal components (PC), inside a vast and heterogenic material. Main categories and thematic groups of the folklore and mythological motifs are processed separately.

The analysis demonstrates the uneven frequency of the occurrence of different groups of motifs in particular regions. Motifs related to the interpretation of the objects of the night sky are widespread in Northern Eurasia from which they had been bought to North America. 
Motifs related to the origin of the man, gender and sex and human anatomy are typical for the circum-Pacific region and for the nonAryan India. Both groups are rare in the sub-Saharan Africa. These differences could be a consequence of the independent development of mythologies in the continental Eurasia and in the Indo-Pacific region after their peopling by the modern man. The earliest set of motifs in Siberia consists of the motifs that find parallels in North (but not in South) America and can be dated to the Terminal Pleistocene. The Indo-Pacific set of motifs that is different from the continental Eurasian one must exist in East Asia at least at the time when the peopling of the New World began (ca. 16,000 cal. B.P.). In the Holocene time new spheres of interaction emerged in Eurasia. The analysis of the spread of the episodes of myths sensu stricto demonstrates links between Siberia and the East and Southeast Asia. The opposite set of motifs is widespread across Europe and the Caucasus with an Eastern fringe as far as Xinjiang. The processing of the episodes of the tales of magic and of the animal tales selects the zone of civilizations from the Atlantic to Southeast Asia and contrasts it with Siberia and Eastern Europe. The most recent tendency in the areal spread of the motifs is revealed thanks to processing of tales of magic and realistic tales. Here the Christian Europe is separated from traditions that are affiliated to the Islamic world and the Steppe.

\section{REFERENCES}

1. Uther, H.-J. (2004) The Types of International Folktales. Helsinki: Suomalainen Tiedeakatemia.

2. Berezkin, Yu.E. (2016) Peopling of the New World in light of the data on distribution of folklore motifs. In: Kenna, R., Mac Carron, M. \& Mac Carron, P. (eds) Maths Meets Myths: Quantitative Approaches to Ancient Narratives. Cham, Switzerland: Springer Verlag. pp. 71-89.

3. Berezkin, Yu.E. (2018) Samoyed cosmology in the Siberian-North American context. Uralo-altaiskie issledovaniya - Ural-Altaic Studies. 2(29). pp. 18-29. (In Russian).

4. Berezkin, Yu.E. (2017) Rozhdenie zvezdnogo neba: predstavleniya o nochnykh svetilakh v istoricheskoy dinamike [The birth of the starry sky: ideas about the night luminaries in historical dynamics]. St. Petersburg: RAS.

5. Berezkin, Yu.E. (2009) Why are People Mortal? World Mythology and the "Out-of-Africa” Scenario. In: Peregrine, P.N., Peiros, I. \& Feldman, M. (eds) Ancient Human Migrations. A Multidisciplinary Approach. Salt Lake City: The University of Utah Press. pp. $242-264$.

6. Prates, L., Politis, G.G. \& Perez, S.I. (2020) Rapid radiation of humans in South America after the last glacial maximum: A radiocarbon-based study. PlosOne, July 22. DOI: 10.1371/journal.pone.0236023

7. Williams, T.J., Collins, M.B., Rodrigues, K., Rink, W.J., Velchoff, N., Keen-Zebert, A., Gilmer, A., Frederick, C.D., Ayala, S.J. \& Prewitt, E.R. (2018) Evidence of an early projectile point technology in North America at the Gault Site, Texas, USA. Science Advances. 4. pp. 1-7. DOI: 10.1126/sciadv. eaar5954

8. Bar-Yosef, O. \& Belfer-Cohen, A. (2013) Following Pleistocene road signs of human dispersals across Eurasia. Quaternary International. 285. pp. 30-43. DOI: 10.1016/j.quaint.2011.07.043

9. Bar-Yosef, O. \& Wang, Y. (2012) Paleolithic archaeology in China. Annual Review of Anthropology. 41. pp. 319-335. DOI: 10.1146/annurev-anthro092611-145832

10. Qu, T., Bar-Josef, O., Wang, Y. \& Wu, X. (2013) The Chinese Upper Paleolithic: geography, chronology, and techno-typology. Journal of Archaeological Research. 21.pp. 1-73. DOI: 10.1 007/s 108 1 4-0 1 2-9059-4

11. Higham, C., Higham, T. \& Kijngam, A. (2011) Cutting a Gordian Knot: the Bronze Age of Southeast Asia: origins, timing and impact. Antiquity. 85(328). pp. 583-598. DOI: 10.1017/S0003598X00067971

12. Berezkin, Yu.E. (2009) The Pleiades as Openings, the Milky Way as the Path of Birds, and the Girl in the Moon: Northern Eurasian Ethno-Cultural Links in the Mirror of Cosmonymy. Archaeology, Ethnology \& Anthropology of Eurasia. 37(4). pp. 100-113. (In Russian). DOI: 10.1016/j.aeae.2010.02.012 